\title{
Development and Evaluation of A Mechanical Extractor for Date Palm Fruit Juice
}

\author{
Sunday Reagan Ogblechi ${ }^{1}$ and Moses Toye Ige $^{2}$ \\ ${ }^{1}$ Agricultural Engineering Research Division Nigerian Institute for Oil Palm Research (NIFOR), P.M. B 1030, Benin City, Edo \\ State, Nigeria \\ ${ }^{2}$ Department of Agricultural and Environmental Engineering Obafemi Awolowo University, Ile-Ife, Osun State, Nigeria. \\ ogblechs@yahoo.com, mosesige63@yahoo.com
}

\begin{abstract}
A two-in-one machine (a pulverizer and screw press) was developed to digest a steam-treated date palm fruit (Phoenix dactylifera l.) and a screw press specially developed for extraction of juice which could further be processed into date syrup, date jam, binding ingredients for snacks, etc. The prototype design was fabricated at the Nigerian Institute for Oil Palm Research, NIFOR, Benin City, Edo State - Nigeria. The equipment has a capacity of $250 \mathrm{~kg}$ fruit/hr with an extraction efficiency of $95 \%$. A $2^{4}$ factorial experiment with the following variables: time of sterilization, fruit quantity, water quantity and speed of pulverizer. The effects of these variables on the quantity of juice extracted and their interactions with one another were determined using statistical analysis.

Results showed that the effect of each variable was significant $(\mathrm{P}<0.01)$. Optimum values for machine speed and time of sterilization were $300 \mathrm{rpm}$ and 90 minutes, respectively. The juice extracted was analyzed for total solids, $\mathrm{pH}$, titratable acidity, mineral contents, total and reducing sugars.
\end{abstract}

Index Terms - development, extractor, date juice, performance

\section{Introduction}

Date palms are perennial tree crops of numerous commercial values. Some are grown as ornamental palms, either outdoors or indoors [1] while date Palm Phoenix dactylifera $l$. is cultivated for its fruit ([2]; [3]; [4]; [15]; [6]).

[1] reported that date fruit could be used in about 800 different ways and was described by [7] as a fruit with multiple uses. The fruit is very nutritious, easily assimilated when consumed, energy giving and contain most of the dietary elements ([4]; [5]; [8]; [9]; [10]; [11]). Some of the nutrients include easily digested sugars (glucose and fructose), proteins, iron, magnesium, sodium, phosphorus, potassium and copper. It also contains vitamins such as riboflavin, thiamine, folic and ascorbic acids ([12]; [5]; [8]; [9]; [10]; [11]). Apart from these it contains fibre, pectin and other nutritive substances.

Due to the high nutritive value of the fruit many people wish to exploit it. The energy content of the fruit is over 3,000 $\mathrm{cal} / \mathrm{kg}$. Fruits such as orange, apricot and banana have energy contents of $480 \mathrm{cal} / \mathrm{kg}, 520 \mathrm{cal} / \mathrm{kg}$ and $970 \mathrm{cal} / \mathrm{kg}$, respectively. Cooked rice has $1,800 \mathrm{cal} / \mathrm{kg}$, meat without fat has 2,245 $\mathrm{cal} / \mathrm{kg}$ [4]. The inverted form of sugar (glucose and fructose) unlike sucrose could easily be assimilated by human body when consumed. Inverted sugars are not subjected to normal digestion that ordinary sugar (sucrose) undergoes. It was reported that date palm fruit consumers are known to have the lowest rate of all forms of cancer diseases which may be attributed to the high level of magnesium $(60 \mathrm{mg} / \mathrm{kg})$ present in the fruit ([5]; [8]; [9]; [1]10). It was also reported that the presence of fibre in the fruit helps to aid human digestion and bowel evacuation.

Normally date palm fruit is free from pesticide contamination and may be sold as organic food. It has a low waste content. Ground date seed is used as food for fish farm. Date paste is used to shape and bind ingredients such as nuts, grains, snacks, etc. Syrup extracted from date has a high sweetening taste and could substitute refined sugar (sucrose). Other applications and uses of whole date or extract are in vinegar production, organic acids, enzymes and some antibiotics.

Date fruits are eaten raw locally and substantial quantities are discarded due to low grade fruit quality, inadequate processing techniques and lack of appropriate storage facilities. Plate 1 shows typical Nigerian date palm fruits.

Traditionally, date fruit juice is prepared in Northern Nigeria by soaking digested date in water overnight. This is followed by a quick boil in order to precipitate some of the colloidal matter therein. It is then filtered by means of baft or muslin cloth to give date juice. This method is not efficient because of the drudgery involved. Digestion is done manually by the use of mortar and pestle. The overall process is slow, labour intensive with low output.

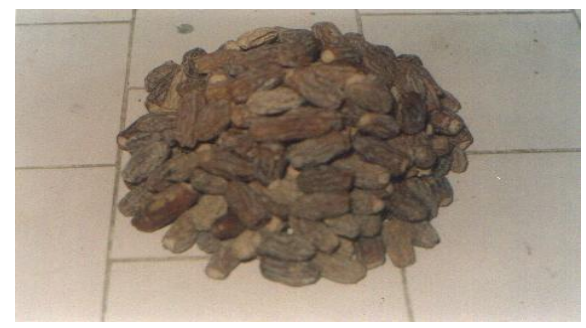

Plate 1: Date palm fruit

Non-alcoholic date juice was obtained by water extraction in the laboratory at the Nigerian Institute for Oil Palm Research (NIFOR), Benin City, Edo State - Nigeria. The laboratory method could not handle large quantity of fruit available in the market and during peak season and may lead to wastage which may subsequently discourage large scale production.

In view of the importance and potentials in the date palm fruit and its extract coupled with the current methods of juice 
extraction, a machine for the extraction of non-alcoholic date juice was developed from stainless steel materials. The machine was subjected to performance evaluation test and juice extracted from the fruit was analyzed for nutrient composition.

\section{Materials and Method}

Date palm fruit used for this study was obtained from the Nigerian Institute for Oil palm Research (NIFOR), Date Palm Substation, Dogon-Dutse, Jigawa State - Nigeria. The materials used for machine fabrication were mainly stainless steel especially those parts of the machine that have direct contact with either the fruit or juice. All the materials used for development of the equipment were procured from local markets.

\subsection{Principles of the design}

Steam - treated date palm fruit required digestion in order to loosen the mesocarp from the seed and to digest and compress the fleshy part which is the mesocarp to extract the juice therein. The embedded seed together with the mesocarp make up the fruit. The seed is not to be damaged or crushed by the machine when in operation.

\subsection{Design of shaft and considerations}

This is principally concerned with the determination of the appropriate shaft diameter to ensure adequate strength and rigidity when the shaft is transmitting power under different operating and loading conditions. Shafts are usually circular in cross section and could either be solid or hollow. Stainless steel shaft is a ductile material and the design is based on its strength. This is determined by the maximum shear theory [13]. Shaft is normally subjected to torsion, bending and axial loads. For torsional loads, the torsion stress for a solid shaft is given by:

$$
\tau_{x y}=\frac{M_{r}}{J}=\frac{16 M_{t}}{\pi d^{3}}
$$

For bending loads, the bending stress, $\mathrm{S}_{\mathrm{b}}$ (tension or compression) for a solid shaft is given as:

$$
S_{b}=\frac{M_{b} r}{I}=\frac{32 M_{b}}{\pi d^{3}}
$$

The tensile or compressive stress, $S_{\mathrm{a}}$ of a solid shaft for axial load is given as:

$$
S_{a}=\frac{4 F_{a}}{\pi d^{2}}
$$

where $\tau=$ Shear Stress,

$\mathrm{d}=$ diameter of shaft,

$\mathrm{M}_{\mathrm{t}}=$ torsional moment,

$\mathrm{M}_{\mathrm{b}}=$ bending moment,

$\mathrm{r}=$ radius of shaft,

$\mathrm{J}=$ polar moment of inertia $\left(\frac{\pi d^{4}}{32}\right)$,

$\mathrm{S}_{\mathrm{b}}=$ bending stress,

$\mathrm{S}_{\mathrm{a}}=$ axial stress,

$\mathrm{F}_{\mathrm{a}}=$ axial load.

American Society of Mechanical Engineer (ASME) Code equation [13] for a solid shaft combines torsion and bending with little or no axial load. The code equation is given as:

$$
d^{3}=\frac{13}{\pi S_{s}} \sqrt{\left(K_{b} M_{b}\right)^{2}+\left(K_{t} M_{t}\right)^{2}}
$$

where $\mathrm{d}=$ shaft diameter,

$\mathrm{S}_{\mathrm{S}}=$ allowable shear stress,

$\mathrm{K}_{\mathrm{b}}=$ shock and fatigue factor for bending, moment,

$\mathrm{K}_{\mathrm{t}}=$ shock and fatigue factor for torsional moment.

Design of shafts for torsional rigidity is based on the permissible angle of twist. The amount of twist permissible depends on the particular application and varies from about 0.3 degree $/ \mathrm{m}$ for machine tool shaft to about $3 \mathrm{degree} / \mathrm{m}$ for line shafts. The angle of twist for a solid circular shaft is given by equation 5 .

$$
\alpha=\frac{584 M_{t} L}{G d^{4}}
$$

where $\mathrm{L}=$ length of shaft in metre,

$\mathrm{G}=$ torsional modulus of elasticity, $\mathrm{N} / \mathrm{m}^{2}$,

$\alpha=$ angle of twist in degree.

Table1 gives the shock and fatigue factors for a rotating shaft [13]. Bending and torsional moments are the major factors considered in shaft design. One of the first steps in the design of a shaft is to draw the bending moment diagram for the loaded shaft or the combined torsional and bending moment diagram if the loads are acting on the shaft in more than one axial plane. The points of critical bending stress are obtained from the bending moment diagram [13]. The torsional moment $\left(\mathrm{M}_{\mathrm{t}}\right)$ acting on the shaft can be evaluated from equation 6 .

$$
M_{t}=\frac{9550 \times k W}{r e v / \min } \text { Newton }- \text { metre }(\mathrm{Nm})
$$

For a belt drive, the torque is calculated from:

$$
\begin{array}{ll}
M_{t}=\left(T_{1}-T_{2}\right) R \text { Newton-metre }(\mathrm{Nm}), \\
\text { where } & T_{1}=\text { tight side of belt on pulley (driver), } N, \\
& T_{2}=\text { loose side of belt on pulley (driven), } N, \\
& R=\text { radius of pulley, } m .
\end{array}
$$

\subsection{Description and operation of the machine.}

The date palm fruit juice extractor described here is a two-in-one machine which operates as an integrated unit. It is driven by a single prime mover. This could be either a $6.0 \mathrm{~kW}$ electric motor or $8 \mathrm{hp}$ diesel engine.

Table 1: Shock and fatigue factors

\begin{tabular}{|l|l|l|}
\hline Nature of loading & $\mathrm{K}_{\mathrm{b}}$ & $\mathrm{K}_{\mathrm{t}}$ \\
\hline Load gradually applied & 1.5 & 1.0 \\
\hline Load suddenly applied with minor shock & 1.5 to 2.0 & 1.0 to 1.5 \\
\hline Load suddenly applied with heavy shock & 2.0 to 3.0 & 1.5 to 3.0 \\
\hline
\end{tabular}

The machine consists of a pulverizer (digester) and an extractor (screw press) mounted on a 60 x 60 angle mild steel frame. Engine (prime mover) speed, pulverizer speed and Screw-press speed were determined by direct measurement 
using an Hasler Tachometer (Hasler AG, 3000 Bern 14, Schweiz, Switzerland).

\subsection{Pulverizer}

The pulverizer pounds the mesocarp and conveys the pounded mass simultaneously. This is the region of the machine where the mesocarps are broken into minute particles without breaking the seeds. The pulverizer has a capacity of 18 $\mathrm{kg}$ of fruit and 54 litres of water per batch. Gold et al. (2000) reported that the optimal fruit to water ratio was 1:3 by mass or volume.

\subsection{Screw Press}

The Screw press separates the liquid component of the pulverized product from the solid components by means of pressure generated by locknut and choke mechanism. The liquid component or solution is passed through a muslin-cloth to exclude particulate matter from the juice.

\subsection{Sample preparation for machine evaluation}

Prior to the pulverization (digestion) of the fruit and subsequent extraction of juice, the fruit is cleaned, washed and sterilized or cooked using a steam pot (Plate 2) with a perforated false bottom. This is to render the nutrients which exist in crystalline forms in the fruits into soluble forms. The sterilized fruits are removed from the steam pot through the discharge outlet by gravity and then taken to the machine for pulverization and subsequent extraction of juice.

\subsection{Experimental design}

A $2^{4}$ factorial experiment as in Table 2 was designed for this study. [15] statistical package was used to analyze the effect and interactions of variables on yield. The variables were time of sterilization, speed of machine, quantity of fruit and quantity of water. These variables were each treated at low $(-)$ and high (+) levels.

\subsection{Extraction efficiency of the machine}

Extraction efficiency of the machine was found from the following relationships.

Extraction efficiency $=$ quantity of juice extracted $(\mathrm{g})$. maximum mass of juice extractable $(\mathrm{g})$

Quantity of juice extracted $=$ mass of fruit processed mass of residual cake* after oven drying.

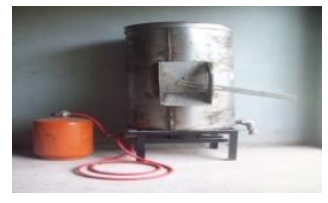

Plate 2: Steam pot

\subsection{Chemical analysis of the juice}

Standard methods of analysis of Association of Official

* This is the solid components obtained after extraction and filtration of date palm fruit juice
Analytical Chemist, [16] were used to determine the compositions of the juice extracted.

\subsection{Preservation and storage}

The juice obtained as a result of filtration was dispensed into $33 \mathrm{cl}$ bottles and each sealed by means of a crown-corking machine. It is then preserved naturally by pasteurizing at $75{ }^{\circ} \mathrm{C}$ for 120 minutes.

\section{Results and Discussion}

Plate 3 shows the developed mechanical extractor for date palm fruit juice while Plate 4 shows samples of date juice. The machine performed satisfactorily with an extraction efficiency of $95 \%$. The percentage of whole date palm seeds obtained after the entire processes of digestion and extraction was almost $100 \%$. Variables such as time of sterilization, machine speed (rpm), fruit quantity and water significantly influenced the yield of juice extracted at $1 \%$ level of probability. Interaction between speed and fruit quantity was significant at $5 \%$. Interactions between sterilization time and water quantity, fruit quantity and water quantity were also significant at $1 \%$ each. However, the interactions between speed and time, speed and water quantity were not significant $(\mathrm{P}<0.05)$.

Prolonged period of sterilization corresponds to high temperature of fruit batch. Comparing time of sterilization for 90 minutes and 60 minutes showed that sterilizing the fruit for 90 minutes gave a better yield than at 60 minutes. This was in agreement with the work done by [17] and [18] who reported that increasing the sterilization temperature of oil palm fruit brings about increase in palm oil yield.

Table 3 shows the yield obtained at different levels of variables. Comparing two different speeds of $420 \mathrm{rpm}$ and 300 rpm for the machine shaft showed that the lower speed of 300 rpm gave higher yields than $420 \mathrm{rpm}$ when these two variables were subjected to the same operating conditions as shown in Table 3. A machine such as a screw press operating at lower

Table 2: Levels of variables

\begin{tabular}{|c|c|c|}
\hline \multirow{2}{*}{ Variables } & \multicolumn{2}{|c|}{ Levels } \\
\cline { 2 - 3 } & Low (-) & High (+) \\
\hline Time of sterilization (minutes) & 60 & 90 \\
\hline Speed of machine (rpm) & 300 & 420 \\
\hline Quantity of fruit (kg) & 1 & 2 \\
\hline Quantity of water (litres) & 5 & 8 \\
\hline
\end{tabular}

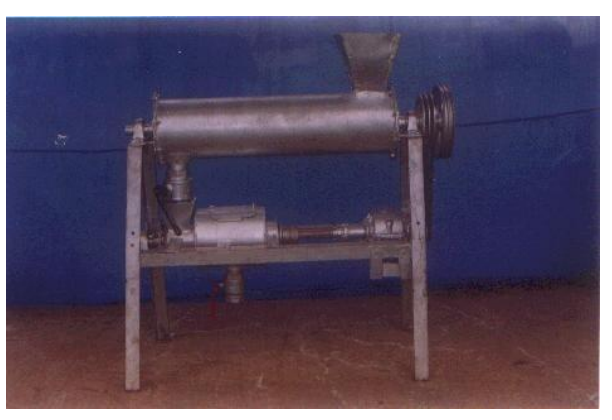

Plate 3: Pictorial view of the mechanical extractor 
speed usually develop high torque required for efficient extraction of biomass, hence the increase in yield at $300 \mathrm{rpm}$. This observation is in agreement with the work done by [19] who reported that low shaft speeds in screw presses give better yield than high shaft speeds. Further results obtained from the study were the compositions and samples of date juice shown in Table 4 and Plate 4, respectively. It was however, read from literature that the date palm fruit contains more nutrients than the ones presented in this paper.

Table 3: Juice Yield Obtained Using the Mechanical Extractor

\begin{tabular}{|c|c|c|c|c|c|}
\hline Exptal run & $\begin{array}{c}\text { Quantity of } \\
\text { water (litres) }\end{array}$ & $\begin{array}{c}\text { Time of } \\
\text { sterilization } \\
\text { (minutes) }\end{array}$ & $\begin{array}{c}\text { Quantity of } \\
\text { fruit }(\mathrm{Kg})\end{array}$ & $\begin{array}{c}\text { Speed of } \\
\text { machine } \\
(\mathrm{rpm})\end{array}$ & $\begin{array}{c}\text { Juice } \\
\text { yield }(\mathrm{Kg})\end{array}$ \\
\hline 1. & 5 & 60 & 1 & 420 & 0.03589 \\
\hline 2. & 8 & 60 & 1 & 420 & 0.04718 \\
\hline 3. & 5 & 90 & 1 & 420 & 0.04956 \\
\hline 4. & 8 & 90 & 1 & 420 & 0.05114 \\
\hline 5. & 5 & 60 & 2 & 420 & 0.08954 \\
\hline 6. & 8 & 60 & 2 & 420 & 0.09434 \\
\hline 7. & 5 & 90 & 2 & 420 & 0.09833 \\
\hline 8. & 8 & 90 & 2 & 420 & 0.10982 \\
\hline 9. & 5 & 60 & 1 & 300 & 0.04851 \\
\hline 10. & 8 & 60 & 1 & 300 & 0,05258 \\
\hline 11. & 5 & 90 & 1 & 300 & 0.05911 \\
\hline 12. & 8 & 90 & 1 & 300 & 0.06534 \\
\hline 13. & 5 & 60 & 2 & 300 & 0.11843 \\
\hline 14. & 8 & 60 & 2 & 300 & 012052 \\
\hline 15. & 5 & 90 & 2 & 300 & 0.13081 \\
\hline 16. & 8 & 90 & 2 & 300 & 0.14382 \\
\hline
\end{tabular}

Table 4: Compositions of date palm fruit juice.

\begin{tabular}{|l|l|l|l|}
\hline Parameter & Unit & Mean value & Standard deviation \\
\hline Vitamin C & $\mathrm{mg} / \mathrm{lm}$ & 0.13 & - \\
\hline Proteins & $\%$ & 1.78 & 0.02 \\
\hline Total sugar & $\%$ & 8.94 & 0.06 \\
\hline Reducing sugar & $\%$ & 7.13 & 0.24 \\
\hline Titratable acidity & $\mathrm{g} / \mathrm{l}$ & 0.48 & 0.01 \\
\hline Total solids & $\%$ & 8.99 & 0.23 \\
\hline $\mathrm{pH}$ & - & 5.07 & 0.15 \\
\hline Iron & $\mathrm{ppm}$ & 94.33 & 1.53 \\
\hline Magnesium & $\mathrm{ppm}$ & 578.43 & 0.45 \\
\hline Calcium & $\mathrm{ppm}$ & 127.93 & 0.88 \\
\hline Phosphorus & $\mathrm{ppm}$ & 342.70 & 0.80 \\
\hline Manganese & $\mathrm{ppm}$ & 31.00 & 1.00 \\
\hline Copper & $\mathrm{ppm}$ & 16.60 & 0.53 \\
\hline Potassium & $\mathrm{ppm}$ & 117.43 & 0.90 \\
\hline Sodium & $\mathrm{ppm}$ & 0.10 & - \\
\hline Lead & - & - & - \\
\hline Cadmium & - & - & - \\
\hline
\end{tabular}

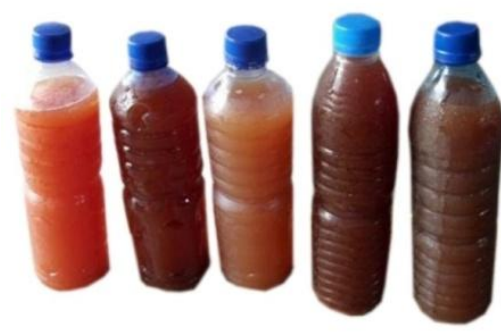

Plate 4: Samples of date juice.

\section{References}

[1] E.C. Okolo, C.O. Okwuagwu and C.D. Ataga. "Flowering and fruiting pattern of date palm in Nigeria." Proceedings of the date palm international symposium, Windhoek, Namibia, 22-25 February, 2000.

[2] J.W. Purseglove. "Monocotyledons". Longman, London, vol., 1 and 2, 1975.

[3] G. Wrigley. "Date palm phoenix dactylifera, evolution of crop plants." Longman publisher, London, $2^{\text {nd }}$ edition, pp 399-403, 1995.

[4] A. Zaid and P.F. Wet. "Origin, Geographical distribution and nutritional value of date palm," 1999.

[5] G. Sanderson. "Natural history of the date palms (Phoenix dactylifera Linnaeus)," Websitehosting freeservers.com, 2001.

[6] A. Walid and R. J. Marshall. "The fruit of date palm: its possible uses as the best food for the future." International Journal of Food Science and Nutrition, $\quad$ http://www.informaworld.com/smpp/contentdb=allcontent=a713995031), vol., 54 no. 4 pp 247-259, 2003.

[7] V.H.W. Dawson. "Date production with special reference to North Africa and the Near East." F.A.O Plant Production and Protection, vol., 39 no. 162, paper $156,1982$.

[8] S. A. El-Sohaimy and E. E. Hafez. "Biochemical and nutritional characterization of date palm fruits (Phoenix dactylifera L.)." Journal of Applied Sciences Research, vol., 6 no.8, pp 1060-1067, 2010.

[9] A.F. El Arem, G. Saafi, E. B. Issaoui, M. Zayene, N. Ferchichi, A. Hammami, M. Helal, A. N. and L. Achour. "Chemical and aroma volatile compositions of date palm fruit (Phoenix dactylifera 1.) at three maturation stages." Food Chemistry, Elsevier, vol., 127, no.4, pp 17441754, 2011.

[10] B. S. Emna, L. Mouna, E. Abdelfattah, Z. Abdelfattah, F. N. Mohamed, H. Mohamed and A. Lotfi. "Protective effect of date palm fruit extract (Phoenix dactylifera 1.) on dimethoate induced oxidative stress in rat liver." Experimental and Toxicologic Pathology, Elsevier, vol., 63, pp 433-441, 2011.

[11] E. E. Eugene, E. Mohammed and G. Larisa. "On farm diversity of date palm (Phoenix dactylifera) in Sudan." A potential Genetic Resources Conservation Strategy, www.mdpi.com/journal/sustainability, pp 339340, 2013.

[12] F.J. Morton. "Food of Warm Climates." Journal of Food Technology. Website Hostingfreeservers.com, 1987.

[13] A.S. Hall, A.R. Holowenko and H.G. Laughlin. "Theory and problems of machine." Schaum's outline series, S.I. metric edition, McGraw-Hill, New York, 1980.

[14] I.L. Gold, D.O.M. Enonuya and M.E. Bafor. "Preparation and clarification of date palm fruit juice." A paper presented at the Chemical Society of Nigeria (CSN), $23^{\text {rd }}$ Annual International Conference, Awka - Nigeria, 2000.

[15] "SAS Institute," Cary, North Carolina, SAS/STAT Users Guide vol., 8, 2000.

[16] "AOAC." Association of Official Analytical Chemist. Washington, D.C., $14^{\text {th }}$ edition, 1984 .

[17] O.K. Owolarafe. Performance evaluation of the digester screw press in oil palm fruit processing. M.Sc. Thesis, Obafemi Awolowo University, Ile - Ife, 1999.

[18] O.O. Babatunde. "Sterilization and mechanical digestion of oil palm fruits." PhD Thesis, Department of Agricultural Engineering, University of Ife, Ile-Ife, Nigeria, 1987.

[19] V.S. Vadke and F.W. Sosulski. "Mechanics of oil expression from Canola." Journal of American Oil Chemical Society, vol., 65 pp 1171 1174, 1988. 